\title{
Release of Lipoprotein Lipase Induced by L-Arginine in Mouse Mammary Tumor FM3A Cells
}

\author{
Tetsuo Morita,* Maki Takada, Sachie Morinaga, Chiemi Kinoshita, and Rie Kerakawati \\ Department of Biochemistry, Faculty of Pharmaceutical Sciences, Fukuyama University, 985 Higashimura, Fukuyama, Hiroshima \\ 729-0292, Japan
}

(Received September 19, 2008; Accepted October 14, 2008; Published online October 15, 2008)

The nitric oxide (NO)/cyclic guanosine 5'monophosphate (GMP) pathway remains undefined regarding the regulation of lipoprotein lipase (LPL) release. Here, we investigated whether $L$-arginine (Arg) stimulates the release of LPL from mouse mammary tumor FM3A cells in a time- and dosedependent manner. L-Arg-stimulated release of LPL activity was inhibited by $\mathrm{N}^{\mathrm{G}}$-monomethyl-L-Arg monoacetate, which is an endothelial NO synthase (NOS) inhibitor. Furthermore, release of enzyme activity was also suppressed by various inhibitors of guanylate cyclase and adenylate cyclase, as well as cyclic GMP- and cyclic adenosine 5'-monophosphate (AMP)-dependent protein kinases (PKG and PKA). L-Arg also increased intracellular cyclic GMP contents as well as intracellular cyclic AMP contents. In addition, the increase in the cyclic AMP contents was reduced by inhibitors of guanylate cyclase and PKG. These results suggest that the stimulatory release of LPL from tumor cells by L-Arg is partly due to activation of cyclic AMP production and PKA activity caused by elevated cyclic GMP production and PKG activity.

Key words — L-arginine, lipoprotein lipase, mammary tumor, cyclic AMP, cyclic GMP

\section{INTRODUCTION}

L-arginine (L-Arg) is considered to be a semiessential amino acid. L-Arg induces production of nitric oxide (NO), which is a multifunctional messenger, by NO synthase (NOS), and it has been reported that $\mathrm{NO}$ is an endothelium-derived

\footnotetext{
${ }^{*}$ To whom correspondence should be addressed: Department of Biochemistry, Faculty of Pharmaceutical Sciences, Fukuyama University, 985 Higashimura, Fukuyama, Hiroshima 7290292, Japan. Tel.: +81-84-936-2111 (Ext. 5221); Fax: +8184-936-2024; E-mail: morita@ fupharm.fukuyama-u.ac.jp
}

relaxing factor that can increase cyclic guanosine $5^{\prime}$-monophosphate (GMP) content in smooth muscle cells by stimulating guanylate cyclase. ${ }^{1-3)}$ It has also been reported that NO participates in physiological actions, such as the promotion of the lipid metabolism and the secretion of growth hormones in the living body. The growth of tumor cells is affected by NO formation; however, the details remain under investigation.

Lipoprotein lipase (LPL) is responsible for the hydrolysis of triacylglycerides in chylomicrons and very low density lipoproteins, and is secreted from various extrahepatic tissues. ${ }^{4,5)}$ Changes in LPL activity are closely correlated with changes in the rate of triacylglyceride uptake of lipids by tissue. ${ }^{6}$ ) It has been observed that increases in LPL activity in Ehrlich ascites tumor cells facilitate the uptake of lipids into tumor cells. ${ }^{7)}$ However, the role of LPL, including its secretion, in the lipoprotein metabolism of tumor cells is largely unknown. ${ }^{8,9)}$

In this study, we show that the release of LPL from mouse mammary tumor FM3A cells is stimulated via a process involving the activation of NO synthesis by L-Arg.

\section{MATERIALS AND METHODS}

Materials — The cyclic GMP enzymeimmunoassay system (RPN226) and cyclic adenosine 5'-monophosphate (AMP) enzymeimmunoassay system (RPN2251) were obtained from Amersham (Tokyo, Japan). L-Arg, N-monomethyl-L-Arg (LNMMA), N-(1-iminoethyl)-L-ornithine (L-NIO), $2^{\prime}, 5^{\prime}$-dideoxyadenosine and methylene blue were purchased from Wako Pure Chemical Industries (Osaka, Japan). KT-5720 and KT-5823 were obtained from Sigma (St. Louis, MO, U.S.A.). H-89 was from Seikagaku Industries (Tokyo, Japan). LY-83583 was obtained from Funakoshi Co., Ltd. 
(Tokyo, Japan). Intralipos, an emulsion composed of $1.2 \%$ yolk lecithin, $2.5 \%$ glycerol and $10 \%$ soybean oil, was from Otsuka Pharmaceutical Co., Ltd. (Tokyo, Japan). All other chemicals used were of analytical grade.

Preparation and Incubation of FM3A Cells Mouse mammary tumor FM3A cells were grown in suspension in a plastic dish $\left(1 \times 10^{4}\right.$ cells $)$ in Essential (ES) medium (Nissui Pharmaceutical Co., Ltd., Tokyo, Japan) containing $10 \%$ fetal bovine serum under an atmosphere of $5 \% \mathrm{CO}_{2}$ in air for 7 days at $37^{\circ} \mathrm{C}$. After removing the medium by centrifugation at $50 \times \mathrm{g}$ for $3 \mathrm{~min}$ at $4^{\circ} \mathrm{C}$ and aspiration, cells in the dish were further incubated for $0-60 \mathrm{~min}$ in a plastic dish $\left(1 \times 10^{7}\right.$ cells $)$ in Hank's medium containing LArg. FM3A cells were then centrifuged at $500 \times g$ for $5 \mathrm{~min}$ at $4^{\circ} \mathrm{C}$. The obtained supernatant served as the preparation for released LPL activity.

Determination of LPL Activity — LPL activity was determined by a method using Intralipos as a substrate. Selective measurement of LPL was based on incubation of LPL with $1 \mathrm{M} \mathrm{NaCl} .{ }^{10)}$ LPL activity was expressed as nmol of free fatty acids (FFA) produced/hr per $10^{6}$ cells. $^{10,11)}$

\section{Determination of Cyclic GMP and Cyclic AMP} Contents - Cyclic GMP was determined in incubated FM3A cells, FM3A cells $\left(1 \times 10^{7}\right.$ cells $)$ were homogenized in ice-cold $5 \%$ trichloroacetic acid (TCA). Supernatants $(10000 \times g)$ were extracted 5 times with 5 volumes of $\mathrm{H}_{2} \mathrm{O}$-saturated diethyl ether and were subjected to quantitative analysis for the cyclic GMP and cyclic AMP.

\section{RESULTS}

Release of LPL from FM3A cells into the medium was observed after the addition of $0.2 \mathrm{mM}$ L-Arg over a 60 -min period. L-Arg linearly stimulated the release of LPL activity in a time-dependent manner (Fig. 1a). Next, FM3A cells were incubated with L-Arg at various concentrations for $60 \mathrm{~min}$. The release of LPL activity was increased in a dosedependent manner up to $0.2 \mathrm{mM} \mathrm{L-Arg}$ (Fig. 1b). When LPL release was stimulated in FM3A cells by L-Arg addition, enzyme activity in the FM3A cells decreased (data not shown).

The possibility of NOS stimulation being involved in the action of L-Arg was then examined. FM3A cells were incubated with L-Arg in the presence of L-NMMA, ${ }^{12}$ which is an L-Arg analog and inhibitor of NOS. An apprecia-
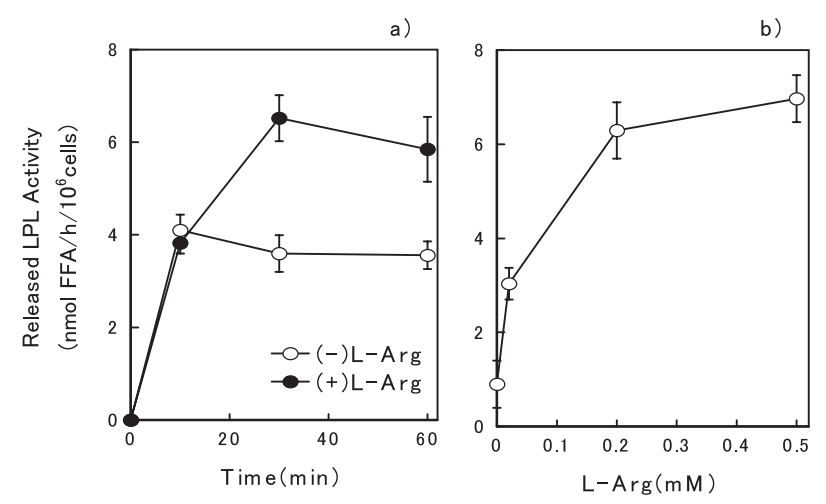

Fig. 1. Stimulatory Effects of L-Arg on Release of LPL from FM3A Cells

a) FM3A cells were incubated for 0-60 min with $(\bullet)$ or with out (O) $0.2 \mathrm{mM}$ L-Arg. LPL in the medium was measured as described in MATERIALS AND METHODS. b) FM3A cells were incubated for 30 min with various concentrations of L-Arg.

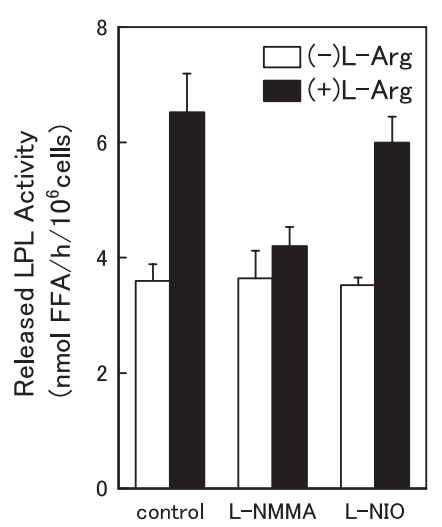

Fig. 2. Effects of L-NMMA and L-NIO on Release of LPL by L-Arg

FM3A cells were incubated for 30 min with (घ) or without (口) $0.2 \mathrm{mM}$ L-Arg addition in the L-NMMA and L-NIO at concentrations of $50 \mathrm{M}$.

ble decrease in the L-Arg-stimulated release of LPL was observed with L-NMMA at concentrations of $50 \mu \mathrm{M}$. However, the stimulatory action of L-Arg was not suppressed by L-NIO, $\left.{ }^{13}\right)$ which is a different type of NOS inhibitor (Fig. 2). The L-Arg-stimulated release of enzyme activity was also suppressed by inhibitors for guanylate cyclase and cyclic GMP-dependent protein kinase (PKG), which were methylene blue ${ }^{14,15)}$ and KT-5823, ${ }^{16,17)}$ respectively. Furthermore, the action of L-Arg was suppressed by inhibitors of adenylate cyclase and cyclic AMP-dependent protein kinase (PKA), which were $2^{\prime}, 5^{\prime}$-dideoxyadenosine ${ }^{18,19)}$ and H-89, ${ }^{20)}$ respectively (Fig. 3).

We then investigated whether the L-Argstimulated release of LPL is involved in cyclic GMP and cyclic AMP contents in FM3A cells. Intracel- 
Table 1. Effects of Inhibitors of Guanylate Cyclase and PKG on Increase in Cyclic AMP Contents in FM3A Cells

\begin{tabular}{lcc}
\hline \hline Chemicals & $\begin{array}{c}\text { Relative cyclicAMP contents } \\
(\%)\end{array}$ \\
\hline \multicolumn{2}{l}{ Methylene Blue $(1 \mu \mathrm{M})$} & $38.4 \pm 2.0$ \\
LY-83583 & $(1 \mu \mathrm{M})$ & $11.9 \pm 1.2$ \\
KT-5823 & $(0.5 \mu \mathrm{M})$ & $0.8 \pm 0.1$ \\
\hline
\end{tabular}

FM3A cells were incubated for $12 \mathrm{~min}$ with or without $0.2 \mathrm{mM}$ L-Arg addition in the presence of methylene blue, LY-83583 or KT-5823. The net contents of cAMP after incubation with L-Arg $(0.2 \mathrm{mM})$ were $0.91 \mathrm{nmol} / 10^{6}$ cells. Percent values were calculated from net contents.

lular cyclic GMP contents and cyclic AMP contents in FM3A cells after addition of $0.2 \mathrm{mM} \mathrm{L-Arg}$ were observed over a 5-min and 16-min period. Timedependent changes in cyclic GMP were seen, and the maximal transient increase was observed after 3 min. Time-dependent changes in cyclic AMP contents were also observed; however, the maximal transient increase was noted after 12 min (Fig. 4). The maximal levels of cyclic GMP and cyclic AMP were two-fold higher than basal levels. A significant increase in the cyclic GMP and cyclic AMP contents of FM3A cells incubated without L-Arg was not observed under these experimental conditions. FM3A cells were also incubated with L-Arg in the presence of inhibitors of guanylate cyclase and PKG (methylene blue, LY-83583 and KT-5823). A marked decrease in cyclic AMP contents was observed (Table 1).

\section{DISCUSSION}

LPL was released from FM3A cells after stimulation by L-Arg (Fig. 1a and 1b). The stimulatory effects of L-Arg were suppressed by NMMA, but were preserved in the presence of NIO (Fig. 2). The L-Arg-stimulated release of LPL activity was suppressed by various inhibitors of guanylate cyclase, PKG, adenylate cyclase and PKA (Fig. 3). Moreover, Fig. 4 shows that cyclic GMP contents and PKG activity were primarily increased by L-Arg, and these increases apparently caused an elevation of cyclic AMP contents and PKA activity in FM3A cells. In other words, the stimulatory release of LPL activity from FM3A cells by L-Arg is due to a process involving the rise of cyclic GMP contents and PKG caused by an elevation in NO production, thus leading to increases in cyclic AMP contents and PKA activity in FM3A cells.

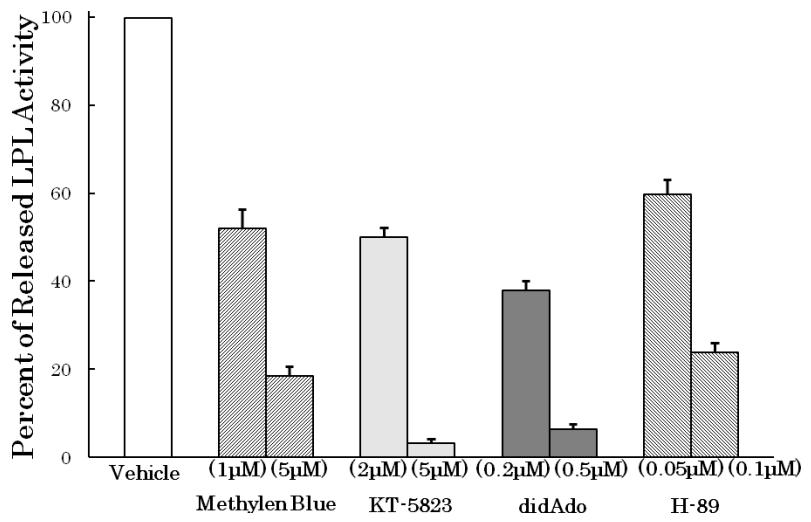

Fig. 3. Effects of Various Inhibitors on the Release of LPL by L-Arg

FM3A cells were incubated for $30 \mathrm{~min}$ with L-Arg in presence of methylene blue, 2', 5'-dideoxyadenosine (didAdo), KT-5823 and H-89.
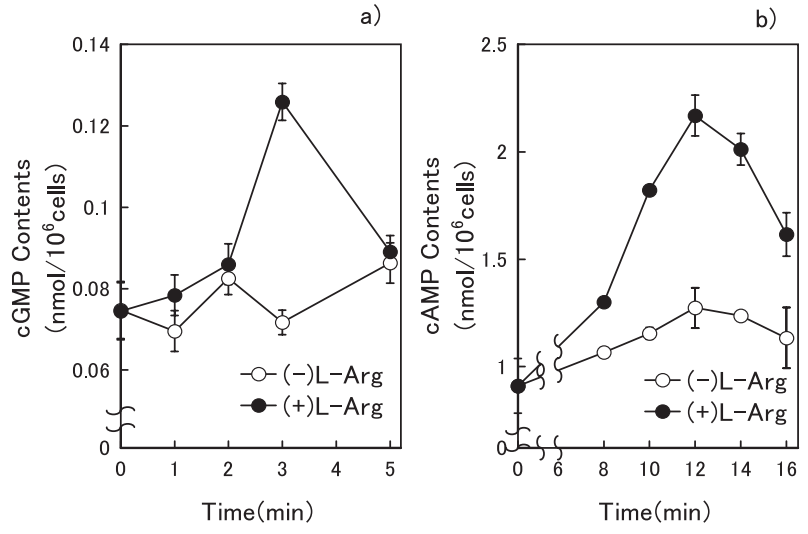

Fig. 4. Increases in Cyclic GMP and Cyclic AMP Contents in FM3A Cells Incubated with L-Arg

FM3A cells were incubated for $0-16$ min with $(\bullet,-\square)$ or without $(\mathrm{O}, \mathrm{\square}) 0.2 \mathrm{mM}$ L-Arg addition. Cyclic GMP and cyclic AMP contents were measured as described in the Materials and Methods.

In macrophages, Renier and Lambert provided evidence of a link between L-Arg metabolism and LPL, which is constitutively expressed by macrophages and synthesized by parenchymal cells. ${ }^{21)}$ According to their report, L-Arg-dependent NO production may be induced by treatment with LPL and interferon-gamma. However, no release of LPL from macrophages and/or parenchymal cells by the addition of L-Arg to medium was shown. NO is known to produce various biological reactions, such as the elevation of cyclic GMP production, ADP-ribosylation and deamination from purine and pyrimidine nucleic acids. ${ }^{1)}$

In this study, the obtained results suggest that the release of LPL from FM3A cells after the addition of L-Arg is due to the activation of PKG and PKA. In addition, NOS reportedly possesses var- 
ious isoforms, ${ }^{22)}$ which have recently been found in cancer cells, including mammary tumor cells. ${ }^{23)}$ Under our experimental conditions, NOS, which is involved in the release of LPL from mouse mammary tumor FM3A cells, was sensitive to NMMA. Thus, it may have been a constitutive type of NOS.

In conclusion, we showed that the release of LPL activity from FM3A cells is stimulated by LArg, and that it may be caused by a process sensitive to elevated NO production and increases in intracellular cyclic GMP and cyclic AMP contents.

\section{REFERENCES}

1) Lowenstein, C. and Snyder, S. H. (1992) Nitric oxide, a novel biological messenger. Cell, 70, 705707.

2) Bredt, D. S. and Snyder, S. H. (1989) Nitric oxide mediates glutamate-linked enhancement of cGMP levels in the cerebellum. Proc. Natl. Acad. Sci. U.S.A., 86, 9030-9033.

3) Nathan, C. (1992) Nitric oxide as a secretory product of mammalian cells. FASEB J., 6, 3051-3064.

4) Salaman, M. R. and Robinson, D. S. (1966) Clearing-factor lipase in adipose tissue. Biochem. J., 99, 640-647.

5) Nisson-Ehle, P. and Garfinkel, A. S. (1980) Lipolytic enzymes and plasma lipoprotein metabolism. Annu. Rev. Biochem., 49, 667-693.

6) Cryer, A. (1981) Tissue lipoprotein lipase activity and its action in lipoprotein metabolism. Int. J. Biochem., 13, 525-541.

7) Balint, Z. and Holczinger, L. (1984) Changes in lipoprotein lipase activity (LPLA) in tumor cells and tissues in mice bearing Ehrlich ascites tumor. Bull. Cancer (Paris), 71, 412-418.

8) Begg, R. W. (1958) Tumor-host relations. Adv. Cancer Res., 5, 1-54.

9) Bloor, W. R. and Haven, F. L. (1956) Lipids in cancer. Cancer Res., 4, 378-416.

10) Morita, T., Shimada, Y., Ueki, H. and Kanagawa, A. (1996) Stimulation of nitric oxide-cyclic GMP pathway by arginine increases the release of hepatic lipase from cultured rat hepatocytes. Biol. Pharm. Bull., 19, 1371-1373.

11) Lee, W. Y., Butler, A. P., Locniskar, M. F. and Fischer, S. M. (1994) Signal transduction pathway(s) involved in phorbol ester and autocrine induction of interleukin-1 alpha mRNA in murine keratinocytes. J. Biol. Chem., 269, 17971-17980.

12) Mollace, V., Salvemini, D., Anggard, E. and Vane, J. (1991) Nitric oxide from vascular smooth muscle cells: regulation of platelet reactivity and smooth muscle cell guanylate cyclase. Br. J. Pharmacol., 104, 633-638.

13) McCell, T. B., Feelisch, M., Palmer, R. M. J. and Moncada, S. (1991) Identification of N-iminoethylL-ornithine as an irreversible inhibitor of nitric oxide synthase in phagocytic cells. Br. J. Pharmacol., 102, 234-238.

14) Tanaka, T. and Hidaka, H. (1980) Hydrophobic regions function in calmodulin-enzyme(s) interactions. J. Biol. Chem., 255, 11078-11080.

15) Kuenzli, K. A., Buxton, I. L. and Bradley, M. E. (1998) Nitric oxide regulation of monkey myometrial contractility. Br. J. Pharmacol., 124, 63-68.

16) Mayer, B., Brunner, F. and Schmidt, K. (1993) Inhibition of nitric oxide synthesis by methylene blue. Biochem. Pharmacol., 45, 367-374.

17) Clementi, E., Sciorati, C., Riccio, M., Miloso, M., Meldolesi, J. and Nistico, G. (1995) Nitric oxide action on growth factor-elicited signals. J. Biol. Chem., 270, 22277-22282.

18) Sabouni, M. H., Cushing, D. J., Makujina, S. R. and Mustafa, S. J. (1991) Inhibition of adenylate cyclase attenuates adenosine receptor-mediated relaxation in coronary artery. J. Pharmacol. Exp. Ther, 259, 508-512.

19) Ogawa, K., Tashima, M., Sawai, H., Toi, T., Sawada, H., Maruyama, Y. and Okuma, M. (1995) Erythroid differentiation and growth inhibition of K562 cells by $2^{\prime}, 5^{\prime}$-dideoxyadenosine: synergism with interferon-alpha. Leuk. Res., 19, 749-755.

20) Fidik, D., Song, Q., Hidaka, H. and Lavin, M. (1995) Protein kinase A inhibitors enhance radiation-induced apoptosis. J. Cell. Biochem., 57, 12-21.

21) Renier, G. and Lambert, A. (1995) Lipoprotein lipase synergizes with interferon gamma to induce macrophage nitric oxide synthetase mRNA expression and nitric oxide production. Arterioscler. Thromb. Vasc. Biol., 15, 392-399.

22) Lee, N. P. and Cheng, C. Y. (2003) Regulation of Sertoli cell tight junction dynamics in the rat testis via the nitric oxide synthase/soluble guanylate cyclase $/ 3^{\prime}, 5^{\prime}$-cyclic guanosine monophosphate/protein kinase $\mathrm{G}$ signaling pathway: an in vitro study. Endocrinology, 144, 3114-3129.

23) Tse, G. M., Wong, F. C., Tsang, A. K., Lee, C. S., Lui, P. C., Lo, A. W., Law, B. K., Scolyer, R. A., Karim, R. Z. and Putti, T. C. (2005) Stromal nitric oxide synthase (NOS) expression correlates with the grade of mammary phyllodes tumour. J. Clin. Pathol., 58, 600-604. 